\title{
Usage of Saliva as Alternative Biological Fluid to Serum for Minerals, Energetic and Hormones Assessment in Lactating Egyptian Water Buffaloes
}

\author{
Abdelghany Hefnawy ${ }^{1, *}$, Saad Shousha ${ }^{2}$, Omnia Abdelhamid $^{3}$ and Seham Youssef ${ }^{4}$ \\ ${ }^{1}$ Department of Internal Medicine; ${ }^{2}$ Department of Physiology; ${ }^{3}$ Department of Biochemistry; ${ }^{4}$ Department of \\ Pharmacology, Faculty of Veterinary Medicine, Benha University, Moshtohor 13736, Egypt
}

\begin{abstract}
Blood sample is the most common biological fluid utilized for diagnosis and monitoring of diseases. Saliva contains locally produced substances as well as serum component, so the aim of this study is to compare the profile of minerals, energetic and hormones in Egyptian water buffaloes. Blood serum and saliva samples were collected from 80 healthy multiparous, non- pregnant lactating Egyptian water buffaloes. Both fluids were tested for sodium, potassium, chloride, calcium, phosphorous, magnesium, insulin, cortisol, ACTH, glucose, urea, creatinine, total protein and immunoglobulin $[\mathrm{IgA}]$. The results revealed that, serum concentrations of calcium, glucose, total protein, sodium, chloride, Insulin, cortisol, ACTH and IgA were significantly higher than saliva. In contrast, the concentrations of potassium and phosphorous in the saliva were significantly higher than that of serum. On the other hand no significant change in respect of urea, creatinine and magnesium was noted between saliva and serum. The relationships between saliva and serum of the estimated parameters were significantly positive except the concentrations of insulin in saliva and blood serum did not correlate. In conclusion, the saliva sample can be used in clinical practice with high level of reliability and provide non-invasive biological fluid for monitoring of different parameters in Egyptian water buffaloes.
\end{abstract}

Keywords: Saliva, serum, buffalo, minerals, energetic, hormones.

\section{INTRODUCTION}

Characteristically, ruminants secrete large volumes of saliva, which has high levels of sodium and high buffering capacity due to the presence of bicarbonate and phosphate in relatively large amounts. Buffering capacity consider the main function of ruminants saliva which has great importance to reduce drop in $\mathrm{pH}$ of the rumen that resulted from fermentation of relatively high grains rations [1].

Saliva shows a good correlation to blood for some analytics, including hormones, and it is collected from humans and from ruminant livestock easily [2-6]. However, there is a time lag between changes in the composition of the saliva and the changes that occur in the blood, and partitioning between the two body fluid compartments is often not simple, making correlation difficult and at times not predictable. Although saliva samples are relatively low in needed compliance, they are still not easy to collect in mid- to large-size animals without considerable restraint [7].

Serum cortisol concentrations have been used as physiological marker of stress in domestic animals [8]. However, interest in non-invasive, easier and quicker quantification method for stress markers has to investigate in saliva as an alternative physiological

*Address correspondence to this author at the Department of Internal Medicine, Faculty of Veterinary Medicine, Benha University, Moshtohor 13736, Egypt; Tel: 00201324603072; E-mail: abdelghani72@yahoo.com medium for cortisol measurement [9] and salivary cortisol measurement is used as a practical surrogate for serum free cortisol [10].

Corticosteroid concentrations can be assayed in saliva, and measures of salivary cortisol concentrations have been used to assess stress reactions in cattle [10-12]. Several authors have demonstrated that corticosteroid concentrations in saliva are directly related to those in plasma in humans, dogs, pigs, and domestic ruminants [7, 13-17]. Others, however, have observed limitations in the extent to which salivary and plasma concentrations are related [18]. Furthermore, little information is available on the relationship between concentrations of corticosteroids in saliva and plasma of buffaloes.

The major cations in saliva are sodium $[\mathrm{Na}+]$ and potassium $[\mathrm{K}+]$ while the main anions are bicarbonate, phosphate and chloride [19]. The total phosphate concentration of saliva in most species is about twice that of plasma [20].

Recycling of phosphorous through saliva is more in ruminants than non ruminants and is stimulated by parathyroid hormone [22].

Several investigators [23-25] have shown that the saliva calcium concentration may be increased in man and dog by raising the calcium level of the blood plasma above normal. However, in clinical conditions, 
such as parturient paresis, salivary calcium was significantly decreased in ewes [26]. A significant amount of magnesium leaves the extracellular fluids to be incorporated into saliva each day. Most but not all of the magnesium in the saliva will be absorbed by the digestive tract and can reenter the extracellular pool [27].

Mucosal IgA detection in oesophago-pharyngeal fluids had potential as an indicator of infection by foot and mouth disease virus in cattle [28-30]. Salivary total protein is a vital component of saliva with salivary protein; predominately comprising proline-rich protein, mucin, amylase, immunoglobulins, satherin and antibacterial factors, and these are responsible for most of functions of saliva [31].

Blood sample is the most common biological fluid utilized for diagnosis and monitoring of diseases. However saliva is frequently studied for diagnostic purpose [32]. The objective of the present study was to make a comparison between saliva and serum concentrations of electrolytes [sodium, potassium and chloride], some hormones [cortisol, insulin and ACTH], glucose, urea, Creatinine, total protein and immunoglobulin $[\lg A]$ and some minerals [calcium, phosphorous and magnesium] and their relationships in lactating Egyptian water buffaloes.

\section{MATERIAL AND METHODS}

Eighty healthy multiparous [3-5 parturitions] nonpregnant lactating Egyptian water buffaloes [age: 6-9 years, body weight $479.6 \pm 5.8 \mathrm{~kg}$, daily milk production: $5.4 \quad \pm 0.2 \mathrm{~kg}]$ were used. Physical examination was performed immediately before sampling. Blood samples were collected via jugular venipuncture into $10-\mathrm{mL}$ vacuum tubes and they were kept at room temperature for 30 to $60 \mathrm{~min}$ and were centrifuged $\left[1,500 \times \mathrm{g}\right.$ at $4^{\circ} \mathrm{C}$ for $\left.15 \mathrm{~min}\right]$. After centrifugation, serum was stored in plastic vials at $-80^{\circ} \mathrm{C}$ until assayed. For each blood sample, a simultaneous salivary sample was collected via oral swab using a $4 \times 8 \mathrm{~cm}$ cotton strip held in surgical forceps, which resulted in the collection of approximately 4 to $5 \mathrm{~mL}$ of salivary volume. Oral swabs lasting approximately $2.5 \mathrm{~min}$ in the mouth of the animals to be adequate to saturate the cotton strip.

Salivary samples were placed in salivette tubes [Sarstedt AG and Co., Numbrecht, Germany] and cooled in ice immediately after collection, then centrifuged $\left[1,500 \times \mathrm{g}\right.$ at $4^{\circ} \mathrm{C}$ for $\left.15 \mathrm{~min}\right]$ and stored at $-80^{\circ} \mathrm{C}$ until assayed. Glucose, urea, creatinine, calcium, magnesium, phosphorus, sodium and potassium, chloride, total protein and immunoglobulin $[\lg A]$ were measured using commercially available kits in both serum and saliva samples, while insulin, cortisol and ACTH were measured by solid phase radioimmunoassay (RIA) using components of a commercial kit (Coat-A-Count, Siemens Medical Solutions Diagnostics, Los Angeles, CA) with modifications described by Kiyma et al. [45].

\section{Statistical Analysis}

The SAS software package [SAS Inst., Inc., Cary, $\mathrm{NC}$ ] was used for analysis of data by means of Student's t-tests. Significance was set at $P<0.05$, and all values were presented as the mean \pm standard error of the mean [SEM]. The relationships between the estimated parameters measured in blood serum and saliva samples were evaluated by Pearson correlation coefficients.

\section{RESULTS}

Concentrations of calcium, glucose, total protein, sodium, chloride, insulin, cortisol, ACTH and IgA in the serum were significantly $[P<0.05]$ higher than that of the saliva, while concentrations of potassium and phosphorous in the saliva were significantly $[P<0.05]$ higher than that of serum while, concentrations of urea, creatinine and magnesium were no significantly changed between saliva and serum as shown in Table 1.

The relationships between saliva and serum of the estimated parameters were significantly positive [ $\mathrm{r}$ from 0.46 to 0.90 and $P<0.05$ ] except the values of insulin in saliva and blood serum did not correlate as shown in Table 1. The total phosphorous concentration of saliva is about twice that of serum concentration while that of potassium in the saliva is about 6 folds of that in serum. The concentrations of $\mathrm{ACTH}$, insulin, creatinine, total protein, $\lg \mathrm{A}$, glucose, chloride and cortisol in the serum are about $18,1.6,1.5,2,15,1.7,2$ and 4 folds of that in saliva respectively, while the ratio between saliva and serum in the urea, calcium,sodium and magnesium was $\sim 1: 1$ as shown in the Table 1.

\section{DISCUSSION}

Blood sample is the most common biological fluid utilized for diagnosis and monitoring of diseases. However, whole saliva is frequently studied as an alternative for blood that can be useful even for 
Table 1: Concentrations of Some Hormones, Electrolytes, Minerals, IgA, Glucose, Total Protein, Urea and Creatinine in Saliva and Serum of Egyptian Water Buffaloes with their Relationships and Ratio. ${ }^{\star} P<0.05$, ${ }^{\star \star} P<0.01,{ }^{\star \star \star}$ $P<0.001$, NS [Non-Significant]

\begin{tabular}{|c|c|c|c|c|c|}
\hline \multirow{2}{*}{ Parameters } & \multirow{2}{*}{ Saliva } & \multirow{2}{*}{ Serum } & \multicolumn{2}{|c|}{ Relationships } & \multirow{2}{*}{$\begin{array}{c}\text { Ratio } \\
\text { Saliva : Serum }\end{array}$} \\
\hline & & & $\mathbf{r}$ & P -value & \\
\hline Cortisol [ $\mu \mathrm{g} / \mathrm{dl}]$ & $0.4 \pm 0.03$ & $1.6 \pm 0.2^{* *}$ & 0.61 & $<0.05$ & $1: 4$ \\
\hline ACTH [ pg/ml] & $1.5 \pm 0.2$ & $27.9 \pm 1.9^{* * *}$ & 0.9 & $<0.01$ & $1: 18$ \\
\hline Insulin $[\mu \mathrm{IU} / \mathrm{ml}]$ & $0.3 \pm 0.02$ & $0.5 \pm 0.04^{* *}$ & 0.17 & NS & $1: 1.6$ \\
\hline Urea [mg/dl] & $38.8 \pm 3.2$ & $37.6 \pm 3.3 \mathrm{NS}$ & 0.57 & $<0.05$ & $1: 1$ \\
\hline Creatinine $[\mathrm{mg} / \mathrm{dl}]$ & $0.60 \pm 0.1$ & $0.90 \pm 0.2 \mathrm{NS}$ & 0.71 & $<0.05$ & $1: 1.5$ \\
\hline Total protein [g/l] & $1.8 \pm 0.4$ & $3.7 \pm 0.3^{* *}$ & 0.54 & $<0.05$ & $1: 2$ \\
\hline $\lg A[\mathrm{mg} / \mathrm{dl}]$ & $5.5 \pm 0.2$ & $85.2 \pm 7^{* *}$ & 0.89 & $<0.01$ & $1: 15$ \\
\hline Glucose [mg/dl] & $47.3 \pm 8.3$ & $80.4 \pm 8.2^{\star *}$ & 0.55 & $<0.05$ & $1: 1.7$ \\
\hline Sodium [mmol//] & $151.3 \pm 1.1$ & $165.7 \pm 0.6^{*}$ & 0.58 & $<0.05$ & $\sim 1: 1$ \\
\hline Potassium [mmol//] & $18.5 \pm 2.7$ & $2.9 \pm 0.2^{* *}$ & 0.82 & $<0.01$ & $6: 1$ \\
\hline Chloride $[\mathrm{mmol} / \mathrm{l}]$ & $37.5 \pm 0.9$ & $71.3 \pm 1.2^{* *}$ & 0.68 & $<0.01$ & $\sim 1: 2$ \\
\hline Calcium [mg/dl] & $9.2 \pm 0.2$ & $11.8 \pm 0.6^{*}$ & 0.63 & $<0.05$ & $\sim 1: 1$ \\
\hline Phosphorous [mg/dl] & $14.9 \pm 2.6$ & $6.8 \pm 1.1^{* \star *}$ & 0.46 & $<0.05$ & $2: 1$ \\
\hline Magnesium [mg/dl] & $2.3 \pm 0.02$ & $2.4 \pm 0.04 \mathrm{NS}$ & 0.67 & $<0.05$ & $\sim 1: 1$ \\
\hline
\end{tabular}

diagnostic purposes [32, 33]. Saliva equilibrates reasonably well with many blood components, but the partitioning between the two body fluids is complex and still poorly understood [2-4]. Saliva can provide diagnostic values, particularly for compounds that are relatively stable in the blood over a reasonable period, or while the animals are at rest and concentrations are within a narrow range [7].

Significant increase in the concentration of glucose and cortisol in blood serum than that of saliva and the positive correlation between them is agreed with [7]. Significant positive correlation between salivary and serum glucose was reported previously [34-36]. Ruminants secrete a large amount of saliva into the rumen, more than 100 liters per day. The phosphorous concentration in cattle saliva is $37-72 \mathrm{mg} / \mathrm{dl}$. These levels are considerably higher than that of bovine blood plasma, which is about $4-8 \mathrm{mg} / \mathrm{dl}$ [22] and this result is agreed with the result of the present study in Egyptian water buffaloes. Therefore, the salivary glands have an important part to play in the regulation and homeostasis of phosphorous [21, 22].

Several investigators [23-25] have shown that the saliva calcium concentration may be increased in man and dog by raising the calcium level of the blood plasma. A significant positive correlation between plasma and parotid saliva calcium and plasma calcium concentration was significantly higher than that of saliva in sheep [26] and this result is agreed with the result of this study.

A significant amount of magnesium leaves the extracellular fluids to be incorporated into saliva each day in goats [27, 42]. Dua and Care [37] postulated that the total magnesium concentration in the mixed saliva of sheep varies between $0.20-0.30 \mathrm{mmol} / \mathrm{l}$. The total amount of saliva secreted by sheep varies between 10 15 liter/day. Thus about $3-4.5 \mathrm{mmol} / \mathrm{l}$ [about $40 \%$ of the total amount of magnesium available in the extracellular fluid] was secreted in the saliva each day. Normally the absorption rate of magnesium was about $20 \%$. So when the animals were in tetany and the absorption of magnesium was grossly impaired and losing these much amount of magnesium through the saliva makes the animals more susceptible to hypomagnesaemia. This was the major reason for which ruminant being more susceptible to hypomagnesaemia than monogastric animals.

Lewis [38] observed urea-nitrogen concentrations from $15-36 \mathrm{mg} / \mathrm{dl}$ in orally collected saliva and this result is agreed with the finding of this study and urea also enters the rumen in saliva and the mechanism of urea transfer from blood to saliva is apparently passive diffusion, as the saliva urea concentration is proportional to BUN. Edward et al. [46] demonstrated 
that BUN and salivary urea concentrations were highly correlated $(r=0.96)$. In this study the salivary creatinine concentrations were about $66 \%$ of serum concentrations and the concentrations were related, while salivary creatinine concentrations were $10-15 \%$ of serum creatinine concentrations in healthy populations and the concentrations were not related in healthy populations, however, a significant relationship was found in the patients $(r=0.784, P<0.001)$ [47].

Characteristically, ruminants secrete large volumes of saliva, which has high levels of sodium and high buffering capacity due to the presence of bicarbonate and phosphate in relatively large amounts [1] and similarly the present study also revealed that saliva has high concentration of sodium in Egyptian water buffaloes. Relative to other nonruminant mammals, the volume of digestive secretions in ruminants is large [43]. This is mainly due to high level of continuous alkaline salivary secretion, which serves to buffer the acid products of microbial fermentation in the rumen provides a medium that facilitates the mixing and regurgitation of ingested materials. The daily volume of salivary secretion in cattle may amount to as much as 100-190 I/day and the amount of $\mathrm{Na}+$ secreted with the saliva may represent $>15$ times the daily amount of $\mathrm{Na}+$ consumed with feed and $>5$ times the amount in all the blood plasma [43, 44]. Potassium concentrations of saliva was significantly higher than that of serum while chloride and sodium concentrations of serum were significantly higher than that of saliva and the findings are in agreement with earlier reports [19, 39].

A significant positive correlation between salivary and serum $\lg A$ may either reflect the activity of $\lg A$ plasma cells underlying the mucosal epithelium or alternatively may occur as a result of transport of $\lg \mathrm{A}$ molecules from the blood circulation [40]. The cortisol concentration in saliva is a direct reflection of the free fraction in the blood [13]. Furthermore, under stress conditions, the binding capacity of cortisol-binding protein becomes saturated, resulting in a disproportionate increase in free cortisol, the fraction that is biologically active [4]. These facts partly explain the differences between concentrations of plasma and salivary cortisol.

Cortisol concentration was higher in serum than in saliva, and a significant positive correlation between salivary and plasma concentrations was in agreement with the earlier reports in sheep in response to introduction of stress [12, 14]. Yates et al. [9] also found a similar relationship between blood serum cortisol and salivary cortisol concentrations in sheep. However, it has been demonstrated that salivary cortisol levels have a steady and predictable relation to the free, unbound cortisol levels in serum and salivary levels accurately reflect serum levels regardless of the degree of stimulation of the salivary glands [39]. Previous studies have found correlation coefficients between cortisol in saliva and cortisol in serum ranging from $r=0.71$ to $r=0.96$ [48]. Little information is available on the relationship between concentrations insulin, ACTH and total protein in saliva and serum of buffaloes and needed further investigations.

According to the results of this work and the significant relationships between salivary and serum concentrations of the estimated parameters, it is possible to use the saliva sample in clinical practice as alternative fluid to serum and provide non-invasive biological fluid for monitoring of different parameters in Egyptian water buffaloes.

\section{REFERENCES}

[1] Beal AM. Electrolyte composition of parotide saliva from sodium-related red kangaroos [Macropus Rufus]. J Exp Biol 1984; 111: 225-37.

[2] Greenwood PL, Shutt DA. Salivary and plasma cortisol as an index of stress in goats. Australian Vet J 1992; 69: 161-3. http://dx.doi.org/10.1111/i.1751-0813.1992.tb07501.x

[3] Cook CJ, Jacobson LH. Salivary cortisol as an indicator of stress in sheep. N Z Vet J 1995; 43: 248. http://dx.doi.org/10.1080/00480169.1995.35902

[4] Cook CJ. Basal and stress response cortisol levels and stress avoidance learning in sheep. N Z Vet J 1996; 44: 162 3.

http://dx.doi.org/10.1080/00480169.1996.35964

[5] Fenske M. Saliva cortisol and testosterone in the guinea pig: measures for the endocrine function of adrenals and testes. Steroids 1996; 61: 647-50. http://dx.doi.org/10.1016/S0039-128X(96)00185-7

[6] Elsaesser F, Klobasa F, Ellendorff F. ACTH stimulation test for the determination of salivary cortisol and of cortisol responses as markers of the training status/fitness of warm blood sports horses. Dtsch Tierarztl Wochenschr 2001; 108 : 31-6.

[7] Cook CJ. Rapid noninvasive measurement of hormones in transdermal exudate and saliva. Physiol Behav 2002; 75 169-81. http://dx.doi.org/10.1016/S0031-9384(01)00658-8

[8] Cohen S, Kessler RC, Gordon LU. Measuring stress. A guide for health and social scientists. Oxford Univ. Press New York, NY 1997.

[9] Yates DT, Ross TT, Hallford DM, Yates LJ, Wesley RL. Technical notes: comparison of salivary and serum cortisol concentration after adrencorticotropic hormone challenge in ewes. J Anim Sci 2010; 88: 599-603. http://dx.doi.org/10.2527/jas.2009-2204

[10] Fell LR, Shutt DA. Adrenocortical response of calves to transport stress as measured by salivary cortisol. Can J Anim Sci 1986; 66: 637-41. http://dx.doi.org/10.4141/cjas86-070 
[11] Cooper TR, Trunkfield HR, Zanella AJ, Booth WD. An enzyme-linked immunosorbent assay for cortisol in the saliva of man and domestic farm animals. J Endocrinol 1989; 123: R13-R16.

http://dx.doi.org/10.1677/joe.0.123R013

[12] Negra JA, Porcionato MA, de Passille AM, Rushen J. Cortisol in Saliva and Plasma of Cattle After ACTH Administration and Milking. J Dairy Sci 2004; 87: 1713-18. http://dx.doi.org/10.3168/jds.S0022-0302(04)73324-X

[13] Riad-Fahmy D, Read GF, Walker RF, Griffiths K. Steroids in saliva for assessing endocrine function. Endocrinol Rev 1982; 4: 367-95.

http://dx.doi.org/10.1210/edrv-3-4-367

[14] Fell LR, Shutt DA, Bentley CJ. Development of a salivary cortisol method for detecting changes in plasma "free" cortisol arising from acute stress in sheep. Aust Vet $\mathrm{J}$ 1985; 12: 403-406. http://dx.doi.org/10.1111/j.1751-0813.1985.tb14120.x

[15] Parrott RF, Misson BH, Baldwin BA. Salivary cortisol in pigs following adrenocotrophic hormone stimulation: comparison with plasma levels. Br Vet J 1989; 145: 362-66.

http://dx.doi.org/10.1016/0007-1935(89)90034-1

[16] Vincent IC, Michell AR. Comparison of cortisol concentrations in saliva and plasma of dogs. Res Vet Sci 1992; 53: 342-45. http://dx.doi.org/10.1016/0034-5288(92)90137-Q

[17] Cook NJ, Schaefer AL, Lepage P, Morgan Jones S. Salivary vs. serum cortisol for the assessment of adrenal activity in swine. Can J Anim Sci 1996; 76: 329-35. http://dx.doi.org/10.4141/cjas96-049

[18] Blackshaw JK, Blackshaw AW. Limitations of salivary and blood cortisol determinations in pigs. Vet Res Commun 1989; 13: $265-71$.

http://dx.doi.org/10.1007/BF00420834

[19] Blair-West JR, Fernley JF, Nelson JF, Marelyn Wintour E, Wright RD. The effect of carbonic anhydrase inhibitors on the anionic composition of sheep's parotid saliva. J Physiol 1980; 299: 29-44

[20] Burgen ASV, Emmelin NG. Physiology of salivary glands. London: Edward Arnold 1961.

[21] Clark RC, Budtz-Otsen OE, Cross RB, Finnamore P, Bauert $P A$. The importance of the salivary glands in the maintenance of phosphorus homeostasis in the sheep. Australian J Agric Res 1973; 24: 913-9. http://dx.doi.org/10.1071/AR9730913

[22] lqbal MU, Bilal Q, Muhammad G, Sajid MS. Absorption, availability, metabolism and excretion of phosphorus in ruminants. Inter J Agric Biol 2005; 7(4): 689-93.

[23] Langley L, Grimes OR, Jr, Cockrell DF. Secretion of calcium and phosphate by the dog parotid gland. Am J Physiol 1961; 201: 599.

[24] Rothman SS, Brooks FP. Effect of hypercalcemia on salivary secretion in the dog. Am J Physiol 1963; 205: 79.

[25] Freeman RM, Welt LG. Parotid fluid calcium and phosphate levels in patients with hypercalcemia. Prec Soc Exp Biol Med 1965; $120: 627$. http://dx.doi.org/10.3181/00379727-120-30609

[26] Smith JC, Stewart WE. Effect of hypocalcemia on the calcium content of the parotide saliva of sheep. J Anim Sci 1968; 27: 1041-44.

[27] Fontenot JP, Ailen VG, Bunce GE, Goft JP. Factors influencing magnesium absorption and metabolism. J Anim Sci 1989; 67: 3445-55.

[28] Archetti IL, Amadori M, Donn A, Salt J, Lodetti E. Detection of foot-and-mouth disease virus-infected cattle by assessment of antibody response in oropharyngeal fluids. $\mathrm{J}$ Clin Microbiol 1995; 33: 79-84.

[29] Salt JS, Mulcahy G, Kitching RP. Isotype-specific antibody responses to foot-and mouth disease virus in sera and secretions of "carrier' and "non-carrier' cattle. Epidemiol Infect 1996; 117: 349-60. http://dx.doi.org/10.1017/S0950268800001539

[30] Amadori M, Haas B, Moos A, Zerbini I. IgA response of cattle to FMDV infection in probang and saliva samples. Report of the Session of the Research Group of the Standing Technical Committee of the European Commission for the Control of Foot-and-Mouth Disease, Borovets, Bulgaria, 5-8 September 2000. Rome: FAO, Appendix 2000; 9: 88-106.

[31] Arati SP, Shirish SD, Rahul RB. Estimation of salivary glucose, salivary amylase, salivary total protein and salivary flow rate in diabetics in India. J Oral Sci 2010; 52(3): 359-68. http://dx.doi.org/10.2334/josnusd.52.359

[32] Bakianian Vaziri P, Vahedi M, Mortazavi H, Abdollahzadeh Sh, Hajilooi M. Evaluation of salivary glucose, IgA and flow rate in diabetic patients: A-case- control study. Journal of Dentistry, Tehran University of |Medical Sciences, Tehran, Iran 2010; 7(1): 13-18.

[33] Kaufman E, Lamster IB. The diagnostic applications of saliva. A review. Crit Rev Oral Biol Med 2002; 13(2): 197-12. http://dx.doi.org/10.1177/154411130201300209

[34] Darwazeh AM, MacFalne TW, McCuish A, Lamey PJ. Mixed salivary glucose level and candidal carriage in patient with diabetes mellitus. J Oral Pathol Med 1991; 20(6): 280-83. http://dx.doi.org/10.1111/j.1600-0714.1991.tb00928.x

[35] Swanljumg O, Merman JK, Torkko H, Sandholm L, Kaprio E, Maenpaa J. Caries and saliva in 12-18 years old diabetics and controls. Scand J Dent Res 1992; 100(6): 310-13.

[36] Amer S, Yousuf M, Siddiqui PQR, Alam J. Salivary glucose concentrations in patients with diabetes mellitus- A minimally invasive technique for monitoring blood glucose levels. Paks J Pharmaceu Sci 2001; 14(1); 33-37.

[37] Dua-K, Care AD. Secretion of magnesium and calcium in the total saliva of sheep and its relevance of hypomagnesaemia. Vet J 1998; 156: 217-21.

http://dx.doi.org/10.1016/S1090-0233(98)80126-3

[38] Lewis D. Blood- Urea concentration in relation to protein untilization in the ruminant. J Agr Sci 1957; 48: 438. http://dx.doi.org/10.1017/S0021859600032962

[39] Berne RM. Physiology $5^{\text {th }}$. Ed. William R. Schmitt 2004.

[40] Scicchitano R, Sheldraket RF, Husband AJ. Origin of immunoglobulins in respiratory tract secretion and saliva of sheep. Immunology 1986; 58: 315-21.

[41] Fell LR, Shutt DA. Salivary cortisol and behavioural indicators of stress in sheep. Proc Aust Soc Anim Prod 1988; 17: 186-89.

[42] AbdElghany $\mathrm{H}$. Research study on magnesium deficiency in goats. Thesis of M.V.Sci. Benha Univ. Egypt 2000.

[43] Bailey CB. Saliva secretion and its relation to feeding in cattle. The rate of secretion of mixed saliva in the cow during eating with an estimate of the magnitude of the total daily secretion of mixed saliva. Br J Nutr 1961; 15: 433-51.

[44] Silanikove N, Tadmor A. Rumen volume, saliva flow rate, and systemic fluid homeostasis in dehydrated cattle. Am J Physiol Regul Integr Comp Physiol 1989; 256: R809-R815.

[45] Kiyma Z, Alexander BM, Van Kirk EA, Murdock WJ, Hallford DM, Moss GE. Effects of feed restriction on reproductive and metabolic hormones in ewes. J Anim Sci 2004; 82: 2548-57.

[46] Keith EO, Ellis JE, Phillips RW, Dyer MEI, Ward GM. Some Aspects of Urea Metabolism in North American Bison. Acta Theriologica 1981; 26(14): 257-68. 
[47] Lloyd JE, Broughton A, Selby C. Salivary creatinine assays as a potential screen for renal disease. Ann Clin Biochem 1996; 33(Pt 5): 428-31.
[48] Kirschbaum C, Hellhammer D. Salivary cortisol in psychoneuroendocrine research: recent developments and applications. Psychoneuroendocrinology 1994; 19: 313-31. http://dx.doi.org/10.1016/0306-4530(94)90013-2 